\title{
THE SUCCESSFUL MODEL OF DISTANCE LEARNING
}

\author{
D. Branekova* \\ Faculty of Education, Trakia University, Stara Zagora, Bulgaria
}

\begin{abstract}
The main focus of the article is the presentation of a model of distance learning in the process of its implementation in the conditions of a global pandemic. A study is included related to the readiness of teachers and students to implement distance learning without time for prior preparation. The influence of the model has been studied on the readiness of the students for learning, as well as the student's attitude to distance learning. Recommendations are made for the development and improvement of the model of distance learning as a component of the university educational environment.
\end{abstract}

Key words: digital learning environment, online learning platforms, electronic learning course, virtual classroom

\section{INTRODUCTION}

The technologicalization of the information society in combination with adequate educational technologies forms a new toolkit of instruments for the realization of both different learning goals and effective tools and methods for learning in a digital educational environment. This environment allows for the development of electronic forms of distance learning, the so-called e-learning (e-learning), which depending on the specifics of the specific technology exists under different forms and names: computer-based learning, internet-based learning, web-based learning, online learning, virtual learning, mobile learning (m-learning), all-pervading/ubiquitous learning (u-learning).

The distance forms of learning make the learner more independent, more active and more responsible for their own development and help for the individual organization of the learning activities. And if this statement, proven by a number of studies, until recently sounded like an opportunity to enrich and develop the university educational environment, then in the context of a global pandemic, distance learning proved to be

\footnotetext{
*Correspondence to: Assoc. Prof Dimitrina Branekova PhD, Trakia University - Faculty of Education, 9 Armejska Str., 6010, Stara Zagora, Bulgaria,e-mail: dbranekova@uni-sz.bg, GSM 0887144353
}

without an alternative both at school and at university. In this situation distance learning started without time for planning and preparation. The results, conclusions and recommendations for the development of distance online learning are more than necessary and are a real challenge for teachers and students.

\section{PURPOSE OF THE RESEARCH}

Opportunities for development of the model for online learning and research of the attitude of the students at the Faculty of Education at Trakia University.

\section{RESEARCH METHODS}

Comparative theoretical analysis, polling, observation

\section{RESULTS AND DISCUSSION \\ The essence of distance online learning}

In the education of students, both in master's and increasingly in bachelor's programs, the view is that the preferred form of education is one that combines elements of distance and traditional learning, as well as the tools and methods ICT offer with traditional methods and tools. Distance learning has historically existed for almost 3 centuries, and has been applied in university education for about 60 or 70 years. In this long history of development, there have been many researchers and definitions concerning the organization methods and means and the way of 
communication between teacher and students, which can be expressed by the following definition: "Distance learning is a set of forms of organization, management methods and means for training using resources that vary in functionality, division by location, mode of participation and time of use" (1). The development of distance learning is based on the development of technologies that most affect the form of learning materials and forms of communication between the participants in the learning process. The types of distance learning are usually determined by the time and place of the training:

- Synchronous traditional training - training at the same time, at the same location of teacher and students;

- Synchronous distance learning - learning in the same real time, with different locations of teacher and students;

- Asynchronous distance learning - training at different (individual) times, with different locations of teacher and students;

- Distributed learning - includes elements of synchronous and asynchronous distance learning.

Real-time online distance learning is based on e-learning, computer-based, and web-based learning. In his scientific work "The Global Campus" Nikolov analyzes the phenomenon of "e-learning" in its various transformations, based on numerous studies, developments and pilot implementations of ICT from a technological, pedagogical, organizational, managerial, economic and political point of view. As a result of the analysis, guidelines for creating a unified electronic educational environment for all higher education institutions in Bulgaria have been outlined (2). Distance online learning creates the so-called "digital educational environment", which must fit into the overall university educational environment. In the pedagogical literature, the digital educational environment is considered to be a complex of means of information and communication technologies with programtechnical, methodical, organizational and methodological character. Zhuk and Sirenko define this environment as "network communication space, which ensures the organization of the educational process, its methodological and informational support, its documentation and interaction between all its subjects" (3). In his study, Forsythe views elearning as "... learning in which the elearning environment is assigned basic educational functions; in this environment and through it the learning of the students is realized and supported and their pedagogical interaction with the teaching resources and materials, with the other students and with the teachers in the process of realization of the educational goals of the course is mediated" (4).

Through the numerous Internet services, the number of universities, colleges, various organizations, freelance TV tutors, etc., which offer distance learning in various fields of human knowledge, is constantly growing in the world. Varbanova-Dencheva reviews elearning in higher education in Bulgaria and her review shows that in all universities in Bulgaria, where pedagogical specialists are trained, to a greater or lesser extent there are integrated e-learning systems. According to the same author, Bulgaria has "achieved the average level of European indicators for the development of the information society and about $63 \%$ of students participate in one way or another in forms of e-learning (5).

Examples of realized virtual environments are the so-called "virtual universities", "virtual academies", "virtual work teams" and others. The university usually uses a combination of different technical solutions or integrates multiple functions to support e-learning. These environments are sometimes called "virtual learning environments", "learning management systems", "content management learning systems", "virtual classrooms", etc.These environments are implemented through a variety of software products - BlackBoard, Moodle, Desire2Learn, N@tschool, Teletop, Sharepoint, etc.

As a unified national e-learning environment in Bulgaria does not yet exist, especially in the unforeseen situation of a pandemic, each training institution uses a platform for organizing e-learning, based on the ability to develop e-learning courses. Most often, universities, schools and other educational institutions in our country use Moodle (Modular Object-Oriented Dynamic Learning Environment) -an e-learning system that provides tools for developing Internet-based educational courses and websites. The main concept of learning embedded in Moodle is social constructivism - learning by sharing and accumulating new knowledge based on old and past experiences. 
During the pandemic, in addition to e-learning platforms, most often Moodle, the software was used to integrate individual ICT components in support of learning (e.g., Skype, e-mail, document sharing, cloud services, YouTube channels, Facebook, etc.).

\section{Readiness to conduct synchronous distance (online) training}

At Trakia University, Stara Zagora, there is a tested and well-functioning integrated Moodle system. It allows for part of the modules to be implemented as e-learning courses, as well as part of one module to be implemented through the e-learning system, and another part traditionally, through face-to-face classes.

Each course contains the necessary teaching materials in which the educational content is set - summarized lectures, in the form of
BRANEKOVA D.

structured texts; texts for additional information; demonstration materials multimedia presentations, videos and movies; practical assignments - creative ones or according to a sample with provided instructions and guidelines; training tests, checklist for self-control, etc.

For the purposes of the research we had a wide range of e-learning courses in various disciplines in the field of informatics, information technologies and their application in education. According to Zaharova, "each elearning course is a complex didactic system that includes the following functional blocks: information-content, control-communication and correction-summarizing"(6). In turn, each block contains resources and activities that perform different didactic purposes (Figure 1)

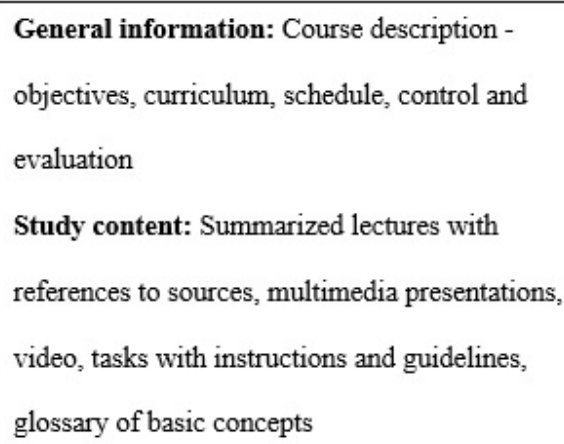

Training tests

Practical tasks with evaluation criteria

Exam tests for evaluating the results in the

discipline

Results from the presentation of the practical

assignments or projects from a face-to-face lesson

Resources created by each student - didactic

materials on a specific topic

Check-lists for self-evaluation

Figure 1. A model of an electronic resource

\section{What was missing for real online learning during a global pandemic?}

The accumulated experience allowed for combining electronic and traditional learning, using elements of asynchronous and synchronous learning, which enriches the learning process with different opportunities for organization and implementation. In this way, most often the author of the course determines the learning content and formulates the learning tasks, and the student uses the learning materials and performs the assignments and tests to be assessed. This leads to limited opportunities for the active cognitive position of the student. For the implementation of distance online learning, in 
the form of a virtual classroom, insufficient was the readiness for:

- Video and audio communication between teacher and students;

- Sharing the screen by the teacher to illustrate the learning content and demonstrate various activities in a real program environment;

- Screen sharing by students to present independent work during an exercise, practical assignment, etc.

- Use of elements of an interactive whiteboard for the purposes of the online lecture;
- Remote control of the screen for consultation and assistance in the implementation of individual tasks by students;

- Recording of the meeting for postponed viewing and listening on the part of the students and the teacher.

The study was conducted in parallel with the process of distance online learning during the summer semester of the academic year 2019 2020. Skype, Team Viewer, Zoom, Google Meet, and Big Blue Button BN were used for the training. Table 1 shows in a systematized way the capabilities of the free versions of these platforms.

Table 1. Functionalities of the platforms for the purposes of distance learning

\begin{tabular}{|l|l|l|l|}
\hline \multicolumn{1}{|c|}{ Platform } & General Functionalities & Additional options & \multicolumn{1}{c|}{ Drawbacks } \\
\hline Big Blue \\
Button BN & $\begin{array}{l}\text { Video and audio } \\
\text { communication } \\
\text { Shared presentation screen, } \\
\text { etc. }\end{array}$ & $\begin{array}{l}\text { Big Blue Button BN и } \\
\text { Zoom have elements of } \\
\text { interactive whiteboard }\end{array}$ & $\begin{array}{l}\text { Zoom there is a time limit } \\
\text { of one meeting within 40 } \\
\text { minutes }\end{array}$ \\
\cline { 1 - 3 } Team Viewer & $\begin{array}{l}\text { Group and individual chat } \\
\text { Recording of the meeting } \\
\text { for postponed listening and } \\
\text { watching the lecture }\end{array}$ & $\begin{array}{l}\text { Team Viewer has } \\
\text { remote control on the } \\
\text { desktop of the } \\
\text { participants in the } \\
\text { meeting }\end{array}$ & $\begin{array}{l}\text { Team Viewer there is a } \\
\text { limit for the number of } \\
\text { participants in the meeting } \\
\text { - up to 5 participants }\end{array}$ \\
\cline { 1 - 1 } Zoom & $\begin{array}{l}\text { Zoom } \text { и Team Viewer } \\
\text { require installation of the } \\
\text { appropriate software }\end{array}$ \\
\hline Skype & &
\end{tabular}

Most of the training was conducted through Big Blue Button $\mathrm{BN}$ due to the following advantages of the program:

- It is integrated into the university platform Moodle and each meeting (virtual classroom) is added as an activity in the respective e-course. In this way, all registered users in the respective course can join the meeting;

- Each student has an account for the university platform Moodle and no additional software is required to be installed

- There is no limit to the duration of the meeting and a large number of participants is allowed;

- The recording of the lecture is stored in the respective meeting (virtual classroom)
- The screen can be shared both by the teacher (moderator of the meeting) and by all students (participants in the meeting).

\section{Results of the study}

The study started at the beginning of the academic year 2019 - 2020 and naturally, in the course of time, two stages were formed: before and during Covid 19. The results of the first stage allowed tracking the change in the students' attitudes to distance learning and served to formulate conclusions and recommendations.

The study was conducted with students from the Faculty of Education in various specialties, Bachelor's degree, Master's degree and forms of postgraduate qualification, studying disciplines related to information technologies and their applications in education (Table 2). 
BRANEKOVA D.

Table 2. Participants in the study

\begin{tabular}{|l|c|c|c|c|}
\hline & Bachelors' Degree & Master's Degree & $\begin{array}{l}\text { Postgraduate } \\
\text { Qualification }\end{array}$ & Total \\
\hline $\begin{array}{l}\text { 1st stage - before } \\
\text { the distance } \\
\text { learning } \\
\text { (Group A) }\end{array}$ & 59 & 64 & 11 & 134 \\
\hline $\begin{array}{l}\text { 2nd stage - during } \\
\text { the distance } \\
\text { learning } \\
\text { (Group B) }\end{array}$ & 71 & 35 & 106 \\
\hline
\end{tabular}

A survey was used, implemented as a Google form shared with the students who were invited to participate on a voluntary basis. The survey was conducted in the school year 2019 2020 in two stages: before and during the distance learning.

The aim of the survey: to study the student's opinion on the quality of distance learning and receiving recommendations for its development and improvement.

\section{Main highlights in the survey}

- Comparison of the number of the used ecourses from the university platform Moodle before and during the emergency situation related to Covid 19 (Figure 2,
- Forms of communication during Covid 19 (Figure 7, Figure 8)

- Students' attitude to exams through online tests (Figure 9)

- Preferred forms of training (Figure 10, Figure 11)

Questions to the surveyed students from group $A$ and group $B$ :

- In how many subjects have you used and/or you are currently actively using an $e$ course? (enter number) (group A)

- How many e-courses from the Moodle platform of Trakia University did you use before the state of emergency? (enter number) (group B)

\section{Figure 3, Figure 4, Figure 5, Figure 6)}

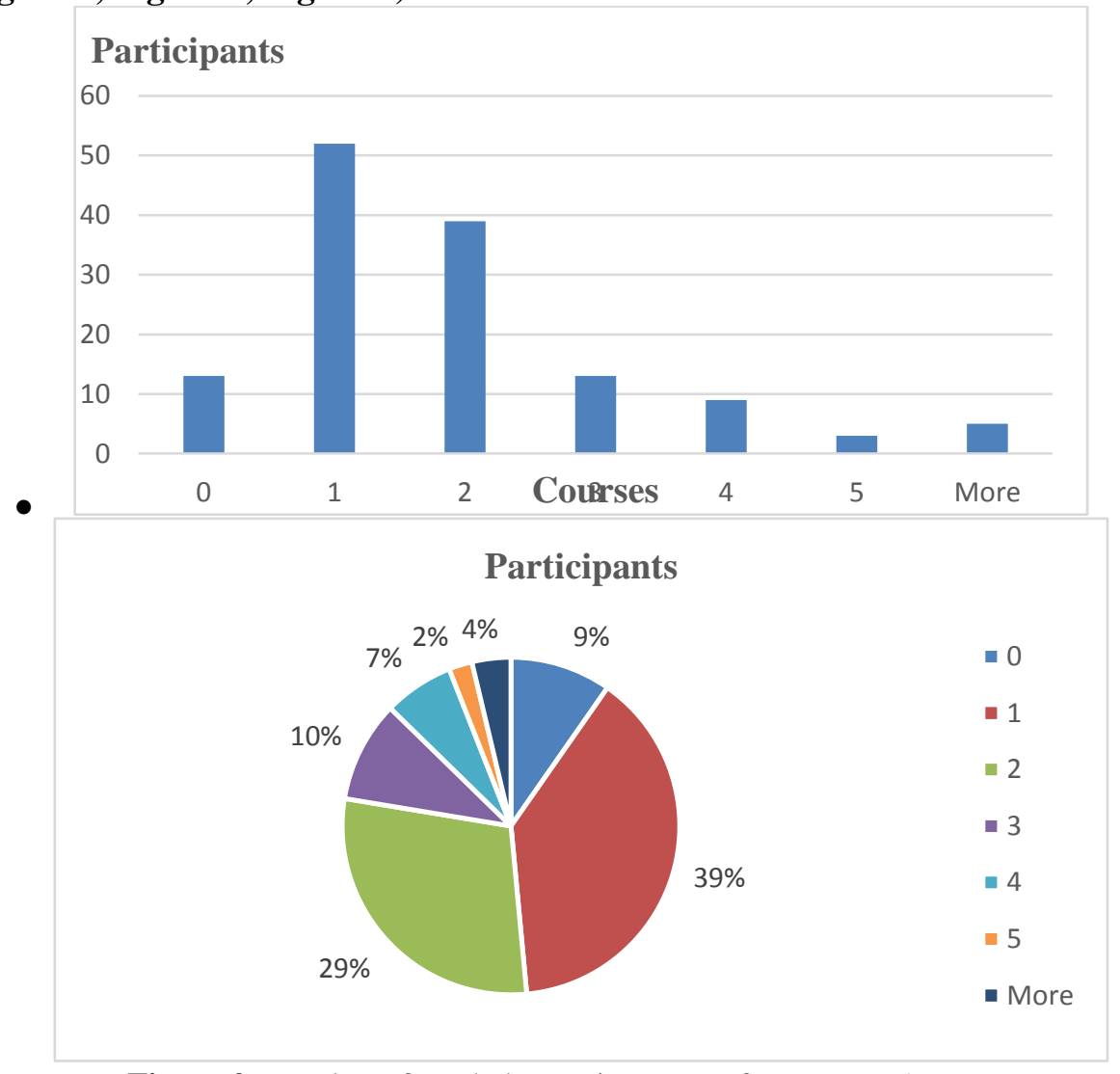

Figure 2. Number of used electronic courses from group A 


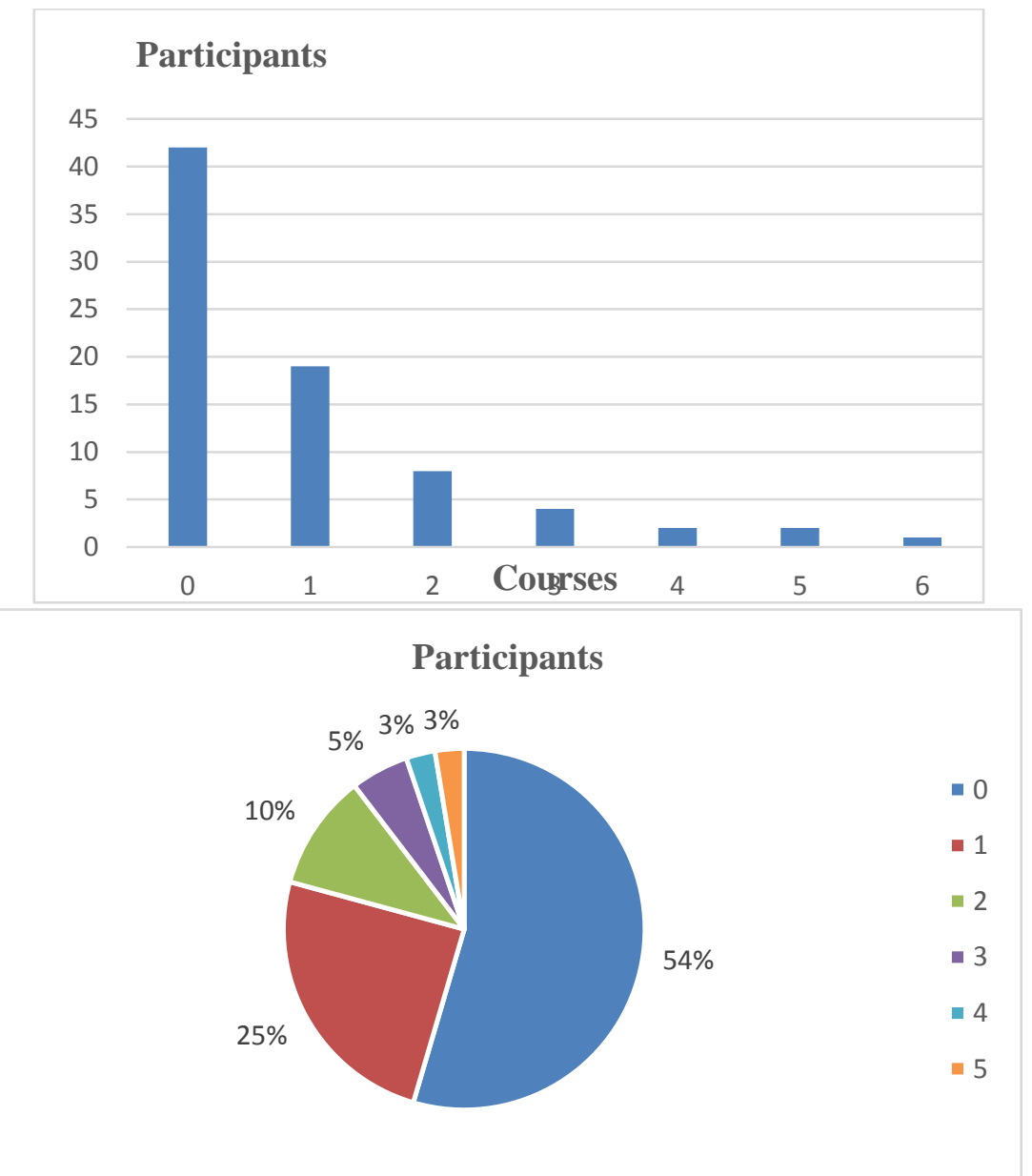

Figure 3. Number of used electronic courses before the state of emergency of group B

The results show that there is no significant difference in the number of courses used before the state of emergency from the two studied groups A and B: 65 participants from group A (49\%) and 52 participants from group
B (63\%) indicate 0 or 1 used electronic course (Figure 2 and Figure 3)

- How many e-courses from the Moodle platform of Trakia University do you currently use during distance learning? (enter number) $(B)$

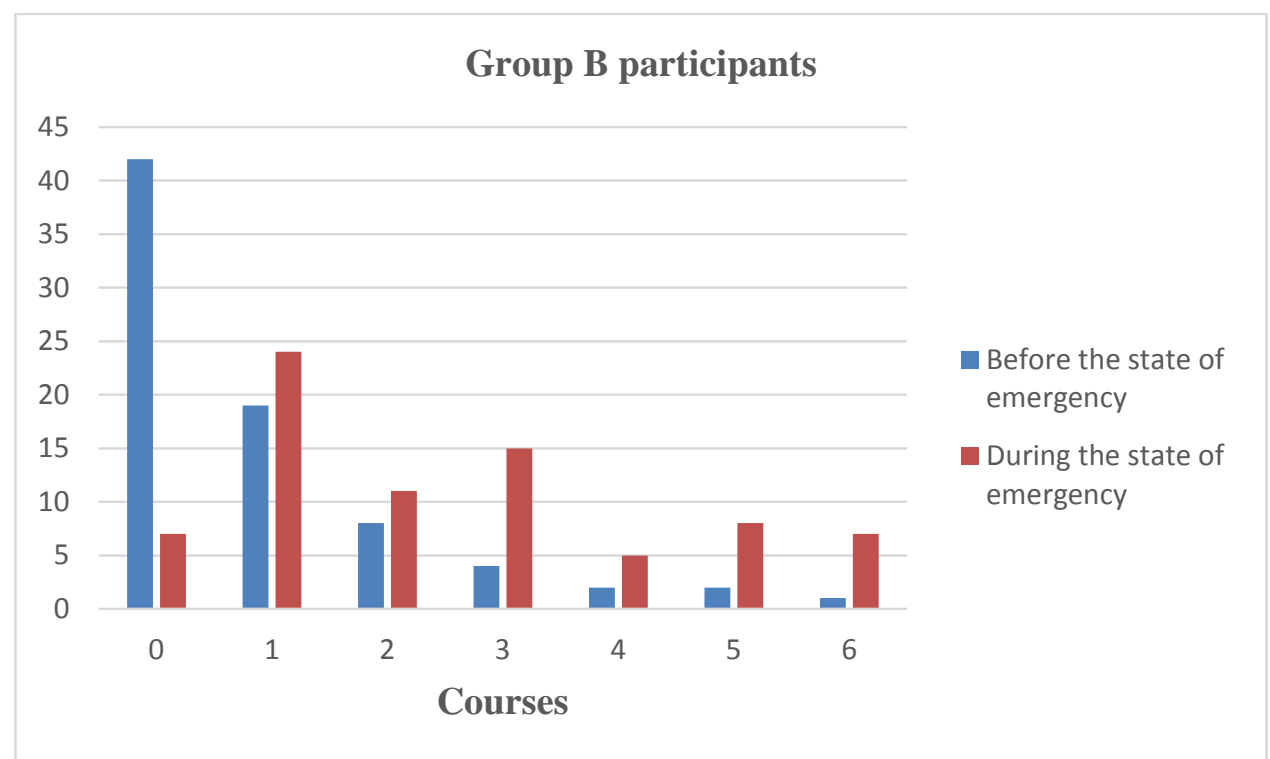

Figure 4. Number of e-courses used before and during the state of emergency by Group B 
From Figure 4 it becomes obvious that the number of students who indicated 0 or 1 course decreased to $31(40 \%)$, while the number of students using more than 1 e-course increased ( $43 \%$ and $16 \%$ before the state of emergency). The research was also interested to find out in the teaching of which subjects students use e-

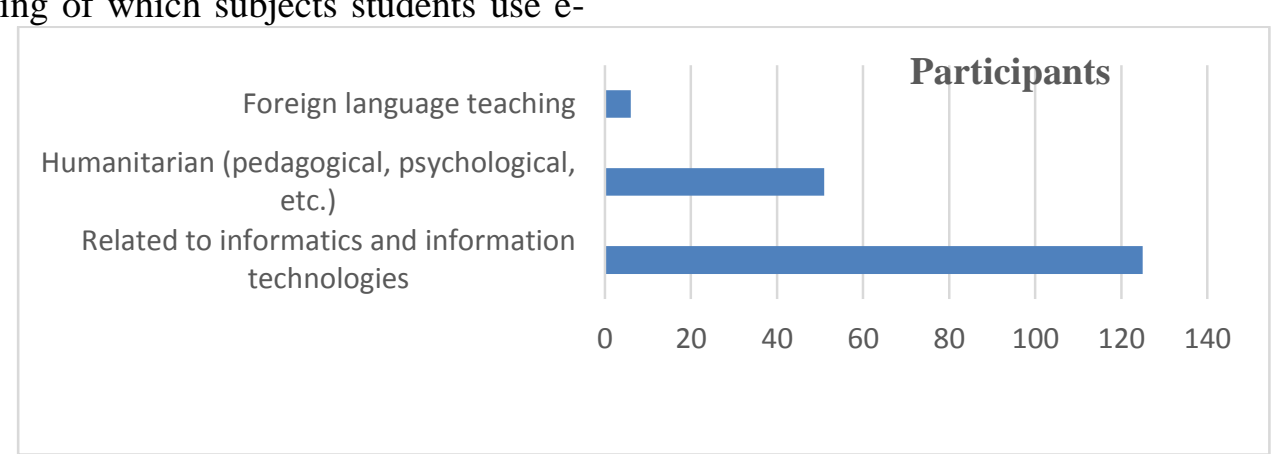

Figure 5. Number of e-courses by types of subjects (group A)

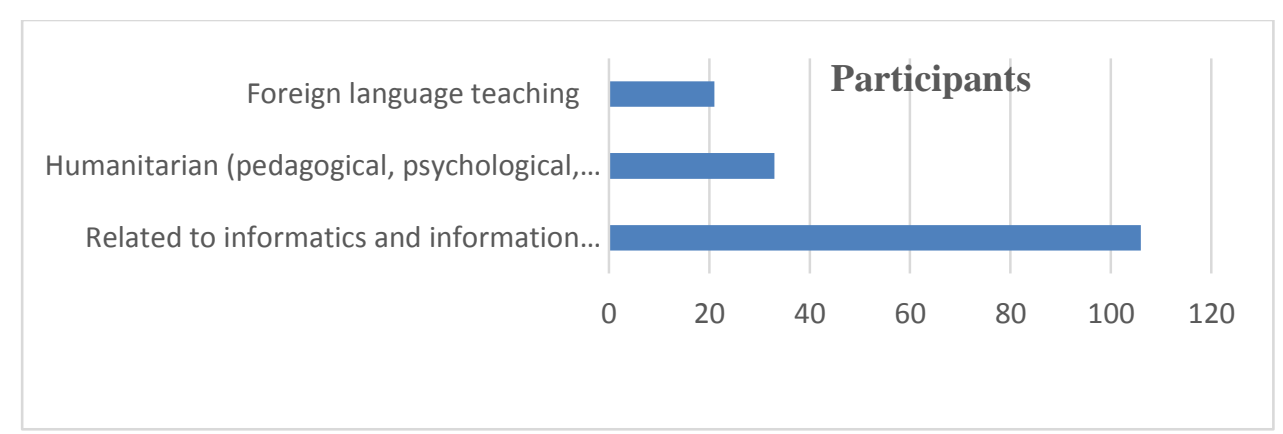

Figure 6. Number of e-courses by types of subjects (group B) during the state of emergency

From the results shown in Figure 5 and Figure 6, it can be concluded that the ecourses used both before and during Covid 19 are mainly in the teaching of disciplines related to informatics and information technologies. That conclusion is supported by the results of courses. The results of the answers to the question: "In which academic disciplines in your education at the Faculty of Education do you use/have you used electronic courses and multimedia textbooks from the electronic platform of Trakia University? (A, B)? 


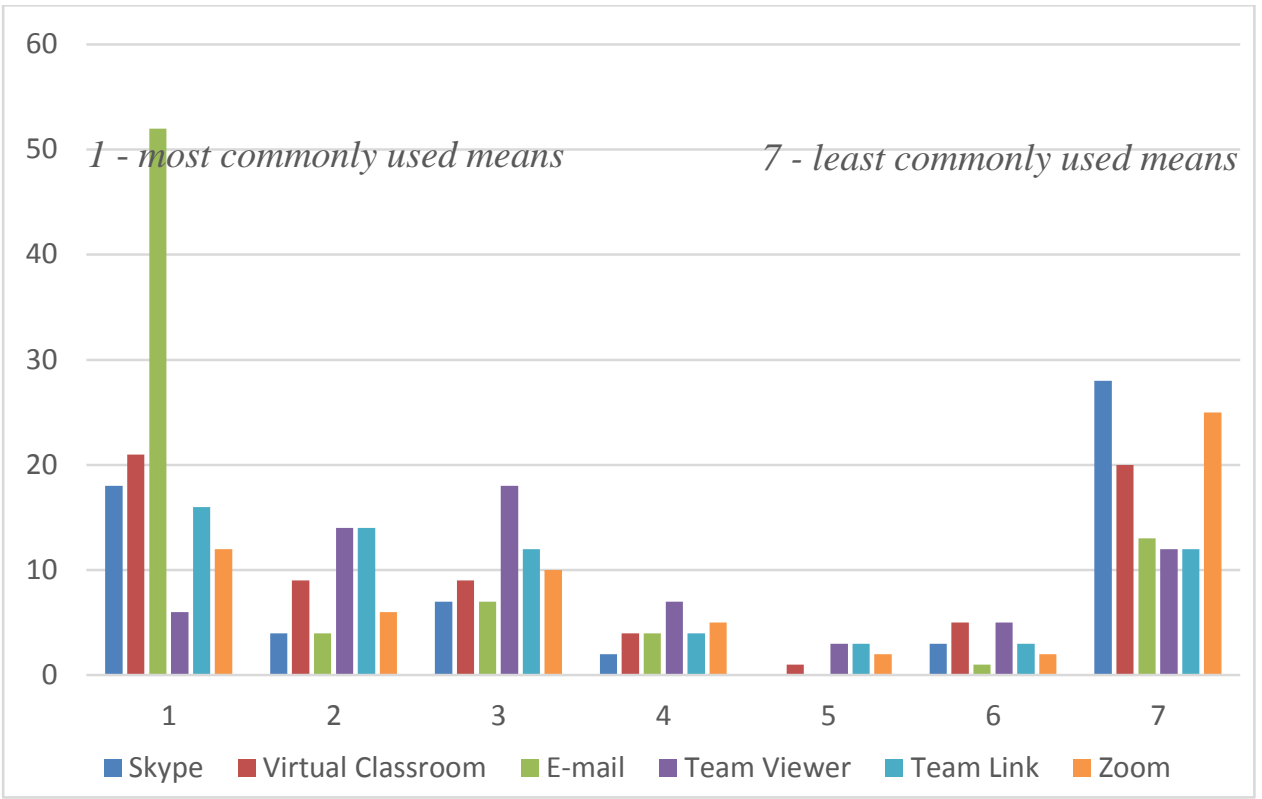

Figure 8. Frequency of using the forms of communication in distance learning

Students indicate e-mail as the most used form $(81 \%)$, and the other forms are indicated by an average of $30 \%$ of the respondents. (Figure 7 and Figure 8)

An important point in the research is the assessment in the conditions of synchronous distance learning through online tests. In this regard, the question to the respondents from group B during Covid 19 is:

Evaluate your agreement on the tests as a way of assessment in the electronic courses of Trakia University, according to the following criteria: $(A, B)$
- Undeservedly high marks are often obtained due to the possibility of a random selection of the correct answer

- Undeservedly high marks are often obtained due to the possibility of copying

- Undeservedly low grades are often obtained due to the impossibility of assessing all knowledge with tests

- The assessment is not objective due to the lack of personal contact between teacher and student

- Exams must always be in attendance

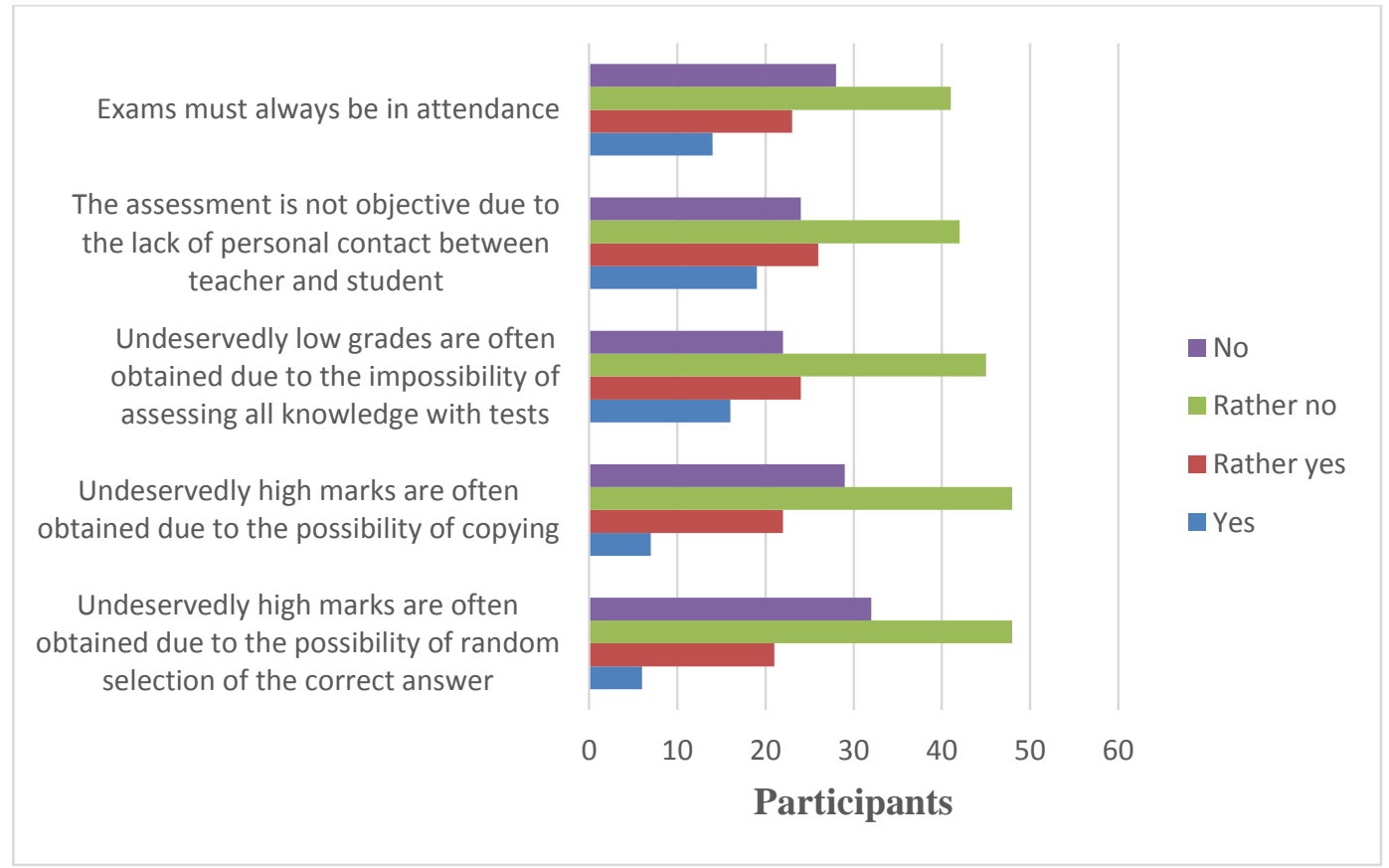

Figure 9. Students' opinion about electronic tests - group B during distance learning 
As a general conclusion from the obtained results, it can be concluded that a large part of the students (on average about 70\%) approve of the examination with electronic tests. The opinion of $30 \%$ of the students who want the exams to always be in presence should not be ignored.

The focus of the study is the students' preferences for the form of education. To the question, "If you have the opportunity to choose a form of education You are for: " the following answers were: $(A, B)$
- Classroom form of traditional education

- Distance learning through electronic forms and electronic resources

- Mostly classroom form with some elements of distance learning

- With an equal share of classroom form and e-learning

The difference in the responses of the students from group A (surveyed before Covid 19) and the students from group B (during Covid 19) is impressive. (Figure 10 and Figure 11)

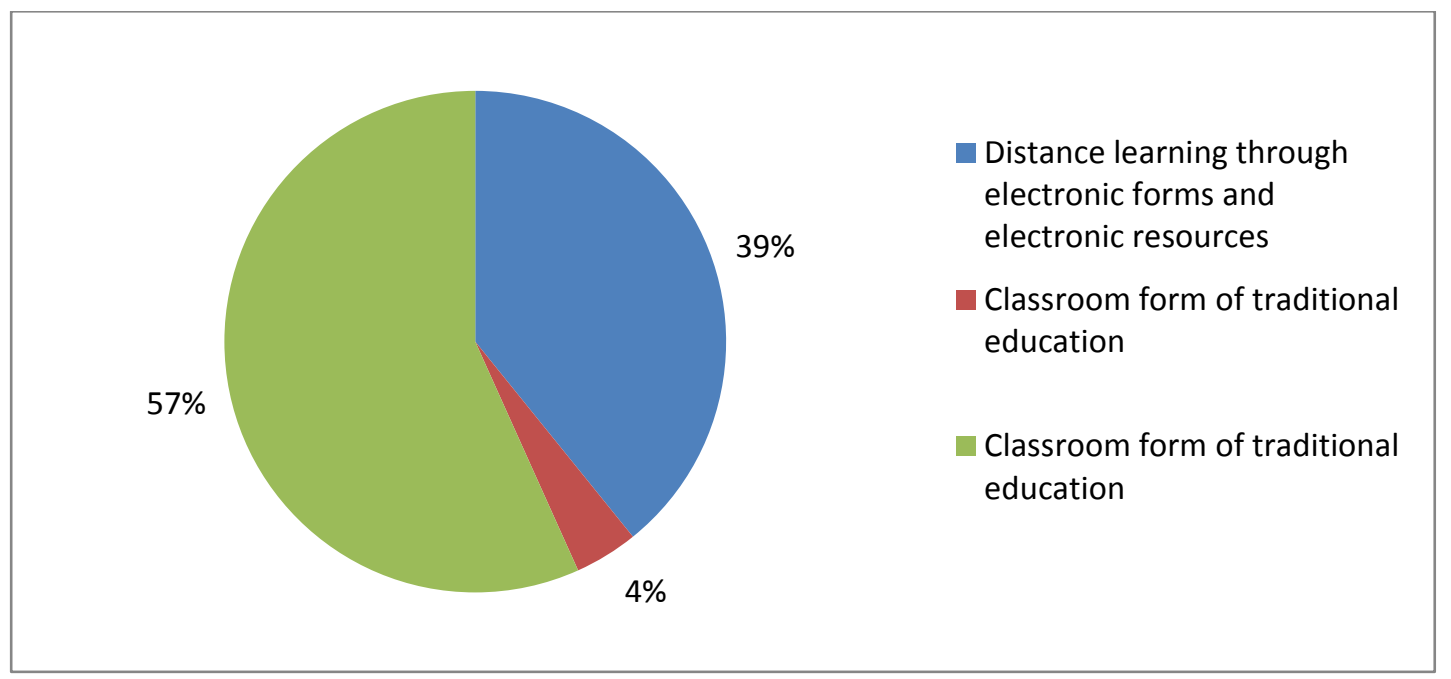

Figure 10. Preferred form of training - group A before Covid 19

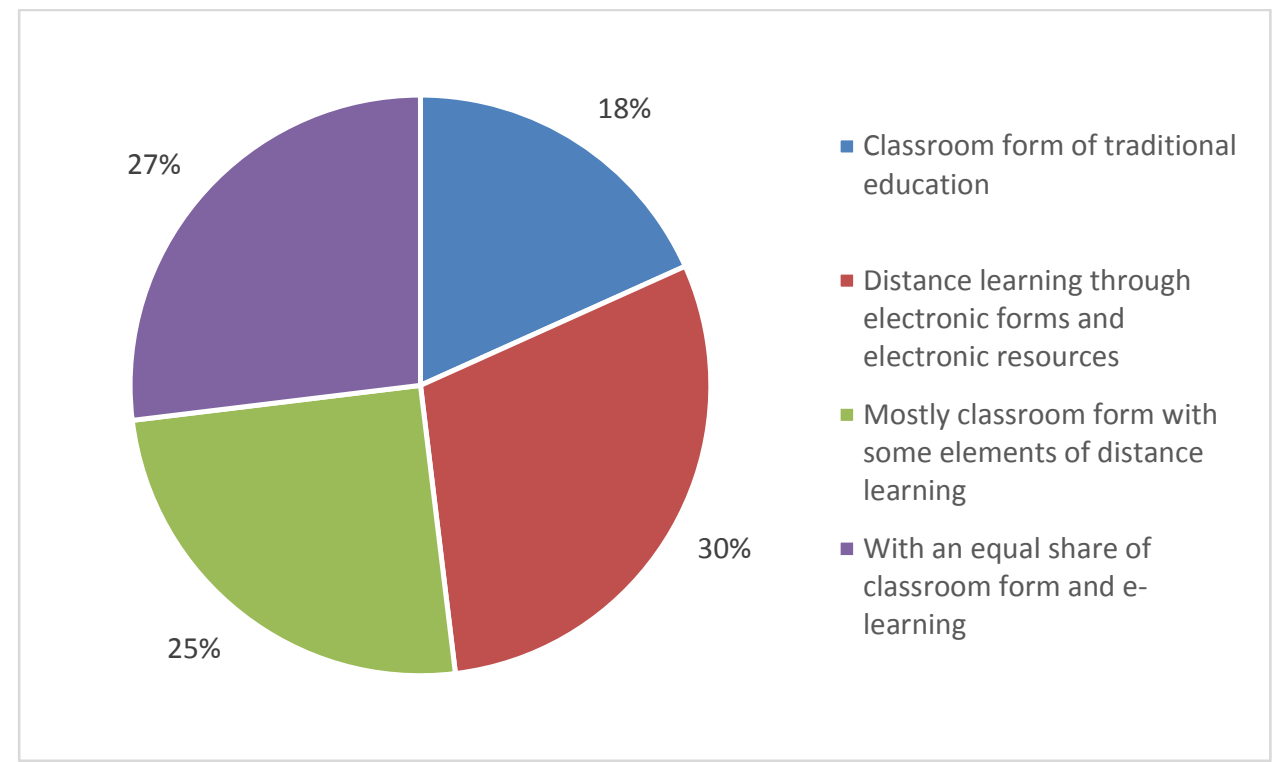

Figure 11. Preferred form of training - group B during Covid 19

Most of the students from group A prefer a combination of face-to-face and distance learning, $4 \%$ of them are for face-to-face form only and $57 \%$ for distance learning.
Most of the students from group B prefer a combination of face-to-face and distance learning, $18 \%$ of them are only for face-to-face and $30 \%$ for distance learning. The change in the results is probably largely due to the desire 
for social communication in the academic environment.

\section{CONCLUSIONS}

The answers of the surveyed students, as well as the recommendations given by them, show that a small part of the distance learning conducted during Covid 19 with them was realized as synchronous distance learning and used mainly asynchronous learning and traditional e-mail. Students approve of distance learning, as well as the control and assessment opportunities it offers. Students prefer the combined forms and recommend the development and improvement of electronic resources for distance learning.

The following recommendations can be made regarding the development and improvement of the distance learning model:

- To improve the digital competence of the teachers for using different platforms for the implementation of online learning and search for the optimal version of the online learning environment.

- To improve the digital competence of teachers to create e-learning content in different disciplines, which motivates students for independent learning and cognitive activity.

- To look for flexible forms for combining different forms of education and optimal integration of electronic forms of distance learning in the university educational environment.

In a pandemic situation, distance learning has no alternative and in this sense it is successful. The extent to which the model of distance online learning will develop and improve, which fits into the university educational
BRANEKOVA D.

environment in various predictable and unpredictable situations depends on the desire and ambition of teachers and students to win the battle for quality education and lifelong learning through the rich and diverse electronic resources that technology provides.

\section{REFERENCES}

1. Totkov, G., A. Eskenazi, R. Doneva, D. Dureva, G. Tuparov i dr. E-obuchenieto v informatsionnoto onshtestvo: tehnologii, modeli, sistemi, dostapnost I kachestvo, PU "Paisiy Hilendarski", 2010 (in Bulgarian)

2. Nikolov, R. Globalniyat kampus, Avangard Prima, 2009. ISBN 978-954-323529-2. (in Bulgarian)

3. Zhuk, O., S. Sirenko. Virtualnaya obrazovatelnaya sreda vuza kak faktar lichnastna-prafesionalnava razvitiya na budushtih spetsialistav, Sbornik s nauchni statii "Pedagogicheskata sreda v universiteta kato prostranstvo za profesionalno-lichnostno razvitie na badeshtiya spetsialist", 2011. APSS, EKSEXPRESS, t. 2, ISBN 978-954-490-244-5. (in Russian)

4. Peycheva-Forsythe, R. Za kachestvoto na elektronnoto obuchenie. http://nissu.eu/Documents/Papers/PeytchevaForsyth_Statia.pdf (last visited by the author on 10.06.2020) (in Bulgarian)

5. Varbanova-Dencheva, K.. Integrirana sreda za elektronno obuchenie - kontseptsiya i savremenno sastoyanie v Bulgaria (primerat na UNIBIT), Obrazovanie i informatsionno obshtestvo, Plovdiv, ARIO, 2012. (in Bulgarian)

6. Zaharova, I. G. Informatsionnae tehnalogii $\mathrm{v}$ abrazavanii, Moskva, izd. tsentar "Akademiya", 2008 (in Russian) 